\title{
Inovasi Cairan Penyanitasi Tangan Dari Bahan Alami
}

\author{
Dhanang Puspita*, Francies Seva Gentaarinda, Irene Maria Lidi, Shara Refla, Nataniel \\ Widyantoro Nugroho, Fransiska Thalita Kusumaningtyas
}

\author{
Teknologi Pangan, Fakultas Kedokteran dan Ilmu Kesehatan, Universitas Kristen Satya Wacana \\ (*dhanang.puspita@uksw.edu) \\ Jl. Kartini No.11a Salatiga, Jawa Tengah, Indonesia
}

\begin{abstract}
Abstrak
Awal pandemi Covid 19 menyebabkan kelangkaan cairan penyanitasi tangan di pasaran. Pemanfaatan senyawa antrimikroba dari tumbuhan menjadi solusi mengatasi permasalahan tersebut. Tujuan dari penelitian ini adalah inovasi pembuatan cairan penyanitasi tangan dari bahan alami. Metode yang digunakan adalah eksperimen laboratis dengan tahapan; invetarisasi tumbuhan, ekstraksi, dan uji antimikroba. Hasil peneliitian diketahui bahwa ekstrak serai, sirih, sirih merah, dan bungan lawang yang dijadikan sebagai cairan pensanitasi tangan memiliki kemampuan sebagai antimikroba. Terdapat senyawa seperti minyak asiri, saponin, polifenol, tanin dan flavonoid pada tumbuhan tersebut yang berfungsi sebagai antimikroba. dapat disimpulkan jika bahan alam seperti sirih, sirih merah, serai, dan kayu lawang memiliki kemampuan antimikroba yang dibuktikan dengan uji antimikroba dengan kekuatan sedang.
\end{abstract}

Kata kunci: antimikroba, bahan alam, penyanitasi tangan.

\begin{abstract}
The beginning of the Covid 19 pandemic caused a shortage of hand sanitizer on the market. Utilization of antimicrobial compounds from plants is a solution to overcome these problems. The purpose of this research is to innovate the manufacture of hand sanitizer from natural ingredients. The method used is a laboratory experiment with stages; plant inventory, extraction, and antimicrobial testing. The results of the study found that the extracts of lemongrass, betel, red betel, and anise flower which were used as hand sanitizing fluids had antimicrobial properties. There are compounds such as essential oils, saponins, polyphenols, tannins and flavonoids in these plants that function as antimicrobials. it can be concluded that natural ingredients such as betel, red betel, lemongrass, and anise flower have antimicrobial abilities as evidenced by antimicrobial tests with moderate strength.
\end{abstract}

Keywords: antimicrobial, natural ingredients, handsanitizer. 


\section{PENDAHULUAN}

Tangan merupakan organ tubuh manusia yang rentan terkontaminasi oleh mikroorganisme seperti bakteri, jamur, dan virus. Tangan juga bisa sebagai agen penular penyakit atau infeksi nosokomial, karena mobilitas dan pergerakannya. Dengan demikian tangan harus mendapat perhatian lebih dalam kebersihan pribadi (personal hygiene). Untuk melindungi tangan dari kontaminasi dan menjadi agen penyebaran mikroba patogen, perlu upaya untuk mensanitasi tangan. Sanitasi tangan yang paling sederhana adalah dengan mencuci tangan dengan sabun dan air mengalir, tidak sembarangan menyentuh barang yang berpotensi terdapat mikroba patogen, dan menggunkan cairan sanitasi saat diperlukan (Acharya et al., 2019).

Cairan penyanitasi tangan (handsanitizer) adalah cairan yang berisikan bahan-bahan yang dapat membunuh mikroorganisme dengan cepat. Panyanitasi tangan adalah solusi saat tidak ditemukan tempat cuci tangan, sehingga dapat menjadi pengganti untuk membebaskan tangan dari mikroorganisme yang ada di tangan. Penggunaan handsanitizer lebih efektif dan efisien bila dibanding dengan menggunakan sabun dan air, karena membunuh mikroba secara langsung, sehingga masyarakat banyak yang tertarik menggunakannya. Kelebihan dari penyanitasi tangan adalah dapat membunuh kuman dalam waktu relatif cepat, karena mengandung senyawa alkohol (etanol, propanol, isopropanol) dengan konsentrasi $\pm 60 \%$ sampai $80 \%$ dan golongan fenol (klorheksidin, triklosan) (Asngad et al, 2018).

Kasus Covid-19 di Indonesia mulai muncul bulan Maret 2020 dan sampai saat ini (Februari 2021) sudah lebih dari 1 juta masyarakat yang terjangkit. Keadaan ini membuat masyarakat sadar akan kebersihan pribadi dan salah satunya dengan penggunaan cairan penyanitasi tangan. Permintaan yang banyak akan cairan penyanitasi tangan dan ketersediaanya yang terbatas membuat harganya meningkat tajam. Upaya untuk mengatasi permasalahan tersebut adalah dengan membuat cairan penyanitasi tangan dari tumbuhan (dari bahan alami). Bahan alami digunakan sebagai pengganti bahan kimia seperti alkohol dan triklosan, karena bahan kimia tersebut bisa berdampak buruk (menimbulkan iritasi dan kulit kering) jika digunakan secara berlebihan (Puspita et all., 2020).

Tumbuhan memiliki senyawa yang disebut dengan antinutrisi. Senyawa tersebut digunakan sebagai perlindungan tumbuhan terhadap predator seperti herbivora atau organisme patogen seperti virus, jamur, dan bakteri. Senyawa tersebut sebagai benteng pertahanan dimana tumbuhan tidak bisa berpindah tempat atau mengindar dari ancaman predator dan mikroorganisme patogen. Senyawa tersebut akan memberikan rasa pahit, getir, asam, dan sepat di lidah dan tidak enak dimakan oleh herbivora, dan dapat juga sebagai antimikroba. Beberapa senyawa antimikroba yang umum dijumpai adalah polifenol, resveratrol, flavanoid, katekin, kuinon, alkaloid, lignin, glikosida, saponin, tanin, terpen, minyak asiri, dan peptida (Ferdes, 2018).

Budaya memanfaatkan tumbuhan atau etnobotani sudah menjadi bagian dari kehidupan masyarakat di Indonesia. Masyarakat Indonesia dalam kehidupan sehari-hari memiliki budaya yang masih dominan akan unsur-unsur tradisional. Keadaan ini didukung oleh keanekaragaman hayati yang berasal dari berbagai ekosistem yang ada di Indonesia (Fauziah et al, 2018). Masyarakat Indonesia telah menggunakan obat tradisional sebagai salah satu upaya dalam penanggulangan masalah kesehatan jauh sebelum layanan kesehatan formal dengan obatobat modernnya menyentuh masyarakat (Kusnadi, 2017).

Thomas Standford Raffles menuliskan ada banyak sekali tanaman obat dam sangat penting dalan dunia kodekteran. Tanaman-tanaman obat tersebut digunakan sebagai obat luka, batuk, dan gangguan saluran pencernaan (Raffles, 2014). . Leluhur orang Indonesia mengajarkan pemanfaatan bahan alam yakni tumbuhan sebagai pengobatan, salah satunya untuk obat luka luar. Dalam perspektif farmakologi, pengobatan ini prinsipnya adalah untuk mencegah infeksi, karena ada senyawa antimikroba di dalamnya. Dengan demikian 
senyawa-senyawa antimikroba bisa dimanfaatkan sebagai bahan pembuatan cairan penyanitasi tangan. Tujuan dari penelitian ini adalah inovasi pembuatan cairan penyanitasi tangan dari bahan alami.

\section{METODE PENELITIAN}

Penelitian ini bersifat kualitatif deskripti dengan eskperimen laboratoris yang dilakukan di Laboratorium mikrobiologi FKIK UKSW pada bulan Maret - November 2020. Informasi tumbuhan diperoleh dari Herbie ( 2015). Adapun tahapannya adalah invetarisasi tumbuhan, ekstraksi, dan uji antimikroba.

\section{Inventarisasi Tumbuhan}

Inventarisasi tumbuhan didasarkan pada pustaka sebagai acuan yakni Herbie (2015). Pengambilan sampel didasarkan pada ketersediaan di lapangan. Sampel tumbuhan diambil di area Kota Salatiga dan Kabupaten Semarang. Kriteria sampel adalah berasal tumbuhan yang memiliki aroma yang baik yakni harum atau sedap serta tidak mengandung bahan-bahan yang bersifat toksik/racun dan menyebabkan alergi. Sampel diambil dalam keadaan segar lalu untuk mempertahankannya dari kerusakan disimpan pada suhu rendah sekitar $4^{\circ} \mathrm{C}$.

\section{Ekstraksi Tumbuhan Obat}

Untuk mendapatkan ekstrak dari tumbuhan dilakukan dengan pencucian untuk memisahkan dengan pengotor. Daun daun sirih merah, sirih hijau, dan serai masing-nasing dirajang dalam ukuran kecil sebanyak $500 \mathrm{~g}$ dicampur dengan aquades sebanyak $1.500 \mathrm{~mL}$ kemudian dikukus selama 15 menit. Setelah itu disaring dengan menggunakan kain saring untuk mendapatkan ekstrak. Untuk bunga lawang, yang digunakan adalah dbunga yang sudah dikeringkan, kemudian dihaluskan dengan cara digerus lalu dilakukan perendaman dengan alkohol $70 \%$ selama 30 menit sembari di aduk. Proses selanjutnya adalah penyaringan dengan kain saring lalu ekstrak diuapkaan di dalam rotary vacuum evaporator pada suhu $50^{\circ} \mathrm{C}$ hingga ekstrak tinggal 30\% dari volume total, (Puspita et al., 2020).

\section{Pembuatan penyanitasi tangan}

Ekstrak tumbuhan sebanyak $90 \mathrm{~mL}$ dicampur dengan witch hazel sebanyal $10 \mathrm{~mL}$. Witch hazel adalah eksttrak Hamamelis virginiana digunakan sebagai pelarut dalam bahan kosmetika. Untuk meningkatkan kualitasnya bisa ditambahkan beberapa tetes minyak asiri kemudian dimasukan dalam botol tertutup rapat (Puspita et al., 2020).

\section{Uji Anti Mikroba}

Media uji antimikroba digunakan Nutrien Agar (Merck) $20 \mathrm{~g} / \mathrm{L}$ dilarutkan dalam aquades kemudian disterilkan dengan menggunakan autoclave pada suhu $121^{\circ} \mathrm{C}$ selama 15 menit pada tekanan 2 atm. Larutan agar kemudian dituangkan dalam cawan petri steril sampai mengeras. Uji antimikroba dengan teknik difusi (sumuran) dengan cara permukaan agar dilubangi dengan pipa kaca steril lalu permukaan agar dioles dengan suspensi bakteri E. Coli yang sudah dibiakan dahulu sebelumnya menjadi suspensi. Cairan penyanitasi tangan kemudian dimasukan dalam lubang sumur sebanyak $100 \mu \mathrm{l}$ dengan menggunakan mikropipet. Inkubasi selama 48 jam dalam inkubator pada suhu $31^{\circ} \mathrm{C}$. Zona hambat bakteri diukur berdasarkan panjang diameter zona terangnya (Greenwood, 1995).

\section{HASIL DAN PMBAHASAN}

Tabel 1 menyajikan daftar tumbuh-tumbuhan dan senyawa antimikroba yang terdapat di dalamnya. Tumbuhan yang digunakan sudah familiar di kalangan masyarakat karena digunakan dalam keseharian baik sebagai jamu maupun bumbu. Dengan demikian tumbuhan tersebut dapat dengan mudah ditemukan.

Tabel 1. Daftar tumbuhan dan senyawa antimikrobanya.

\begin{tabular}{lll}
\hline Nama tumbuan & $\begin{array}{c}\text { Bagian } \\
\text { yang } \\
\text { digunakan }\end{array}$ & $\begin{array}{c}\text { Senyawa } \\
\text { antimikroba }\end{array}$ \\
\hline $\begin{array}{l}\text { Serai } \\
\text { (Cymbopogon }\end{array}$ & $\begin{array}{l}\text { Daun dan } \\
\text { pelepah }\end{array}$ & $\begin{array}{l}\text { Minyak asiri, } \\
\text { saponin, } \\
\text { nardus) }\end{array}$ \\
daun & $\begin{array}{l}\text { polifenol dan } \\
\text { flavonoid }\end{array}$
\end{tabular}




\begin{tabular}{|c|c|c|}
\hline Nama tumbuan & $\begin{array}{c}\text { Bagian } \\
\text { yang } \\
\text { digunakan }\end{array}$ & $\begin{array}{c}\text { Senyawa } \\
\text { antimikroba }\end{array}$ \\
\hline $\begin{array}{l}\text { Sirih hijau } \\
\text { (Piper betle L.) }\end{array}$ & $\begin{array}{l}\text { Daun dan } \\
\text { tangkai } \\
\text { daun }\end{array}$ & $\begin{array}{l}\text { (Bassole et } \\
\text { al., 2011). } \\
\text { Saponin, } \\
\text { flavonoid, } \\
\text { dan polifenol } \\
\text { (Carolia, } \\
\text { 2016). }\end{array}$ \\
\hline $\begin{array}{l}\text { Sirih merah } \\
\text { (Piper } \\
\text { ornatum) }\end{array}$ & $\begin{array}{l}\text { Daun dan } \\
\text { tangkai } \\
\text { daun }\end{array}$ & $\begin{array}{l}\text { Flavonoid, } \\
\text { alkaloid, } \\
\text { tanin, } \\
\text { senyawa } \\
\text { polifenol dan } \\
\text { minyak atsiri } \\
\text { (Lestari, } \\
\text { 2014). }\end{array}$ \\
\hline $\begin{array}{l}\text { Bunga lawang } \\
\text { (Illicium } \\
\text { verum) }\end{array}$ & Bunga & $\begin{array}{l}\text { Saponin, } \\
\text { tanin dan } \\
\text { flavonoid. } \\
\text { (Puspita et } \\
\text { al., 2020) }\end{array}$ \\
\hline
\end{tabular}

Pada tabel 2 merupakan hasil uji antimikroba pada beberapa jenis tumbuhan yang berpotensi sebagai penyanitasi tangan. Zona hambat adalah kemampuan senyawa dalam tumbuhan untuk membunuh dan menghambat pertumbuhan mikroorganisem. Nilai zona hambat dikatakan lemah jika lebarnya $1-5 \mathrm{~mm}$, sedang $6-10$ $\mathrm{mm}$, kuat $10-15 \mathrm{~mm}$, dan sangat kuat $>15 \mathrm{~mm}$ (Davis \& Stout, 1971).

Tabel 2. Hasil uji antimikroba.

\begin{tabular}{lcl}
\hline Nama tumbuhan & $\begin{array}{c}\text { Zona } \\
\text { hambat } \\
(\mathrm{mm})\end{array}$ & $\begin{array}{c}\text { Kategori } \\
\text { Davis\&Stout } \\
(1971)\end{array}$ \\
\hline $\begin{array}{l}\text { Serai } \\
\text { (Cymbopogon }\end{array}$ & $\begin{array}{l}5,71 \pm \\
1,27\end{array}$ & Sedang \\
nardus) & & \\
Sirih hijau (Piper & $9,12 \pm$ & Sedang \\
betle L.) & 2,79 & \\
Sirih merah & $8,86 \pm$ & Sedang \\
(Piper ornatum) & 1,46 & \\
Bunga lawang & $6,2 \pm$ & Sedang \\
(Illicium verum) & 0,76 & \\
Kontrol (alkohol & $15,42 \pm$ & Sangat kuat \\
70\%) & 3,16 & \\
\hline Handsanitizer & $9,43 \pm$ & Sedang \\
komersial & 1,39 & \\
\hline
\end{tabular}

\section{Penyanitasi tangan}

Mayoritas cairan penyanitasi tangan komersial yang ada di pasaran terbuat dari bahan-bahan kimia sintetik. Bahan-bahan kimia sintetik tersebut antara lain alkohol, triklosan, dan hidrogen peroksida. Alkohol, triklosan, dan hidrogen peroksida sangat efektif dalam membunuh mikroorganisme, sehingga menjadi pilihan yang praktis sebagai bahan cairan penyanitasi tangan. Namun, efektifitas tersebut juga berdampak buruk jika pemakaiannya terlalu sering, karena bisa menyebabkan iritasi pada tangan.

Salah satu alternatif cairan penyanitasi tangan adalah dengan memanfaatkan bahan-bahan alam yang memiliki senyawa antimikroba. Bahan alam seperti serai, sirih merah, sirih hijau, dan bunga lawang dapat dengan mudah ditemukan di sekitar kita bahkan diperjual belikan di pasar. Bahan-bahan tersebut sangat lekat dengan keseharian, seperti serai yang digunakan sebagai bumbu dapur, sirih hijau untuk menyirih (nginang dalam bahasa Jawa), bunga lawang (pekak bahasa Jawa) sebagai bumbu dan campuran minuman rempah (wedang uwuh), dan sirih merah banyak dipakai sebagai tanaman hias.

Dalam kajian etnobotani, sirih, sirih merah, serai, dan bunga lawang sudah menjadi bagian dalam pengobatan karena dipercaya memiliki khasiat. Secara ilmiah, pada bahan alam tersebut memiliki senyawa-senyawa yang bersifat antimikroba, yakni mampu membunuh dan menghambat pertumbuhan bakteri. Dengan demikian dapat dimanfaatkan sebagai cairan penyanitasi tangan. Dari hasil analisis uji antimikroba, cairan penyanitasi tangan dari bahan alam memiliki kekuatan sedang, dimana serai memiliki zona hambat yang paling kecil yakni 5,71 $\pm 1,27 \mathrm{~mm}$ dan yang terbesar adalah sirih hijau 9,12 $\pm 2,79 \mathrm{~mm}$. Dibandingkan dengan alkohol $70 \%$ dengan zona hambat 15,42 $\pm 3,16$ dan cairan penyanitasi tangan komersial sebesar 9,43 $\pm 1,39$, kekuatan zona hambat dari bahan alam masih di bawahnya.

Hasil penelitian Suliantari et al (2012) zona hambat sirih hijau sebesar $11 \mathrm{~mm}$ terhadap 
E.Coli., ekstrak sirih merah sebesar $6,3 \mathrm{~mm}$ (Candrasari et al., 2012), serai $8,0 \mathrm{~mm}$ (Poeloengan, 2009), dan bunga lawang 6,2 $\mathrm{mm}$. Kemampuan antimikroba dari bahan alam berdasar beberapa penelitian tersebut memiliki kekuatan senyawa antimikroba masuk dalam kategori sedang, dan kategori kuat hanya pada sirih hijau. Meskipun masuk dalam kategori sedang, setidaknya memiliki potensi dalam membunuh dan menghambat pertumbuhan mikroorganisme, bahkan sirih hijau hampir sama kuatnya dengan cairan penyanitasi tangan komersial.

\section{Serai}

Kandungan kimia dari serai (Cymbopogon nardus) adalah minyak asiri, saponin, polifenol dan flavonoid (Bassole et al., 2011). Kandungan senyawa aktif tersebut, mengindikasikan serai memiliki aktivitas antimikroba yang cukup besar (Jafari et al., 2012). Senyawa yang dominan terhadap efek antimikroba serai adalah golongan senyawa polifenol dan senyawa fenolik lain beserta derivatnya yang dapat menyebabkan denaturasi protein. Senyawa flavonoid berfungsi sebagai antimikroba dengan cara membentuk senyawa kompleks dengan protein ekstraseluler. Kompleks yang terbentuk mengganggu keutuhan membran sel bakteri dengan cara mendenaturasi protein sel bakteri dan merusak membran sel tanpa dapat diperbaiki lagi (Reveny, 2011). Ekstrak etil asetat tanaman serai wangi telah terbukti mempunyai aktivitas antimikroba terhadap Escherichia coli dan Staphylococcus aureus (Hendrik, 2013).

\section{Sirih hijau}

Daun sirih hijau (Piper betle L.) merupakan tanaman yang telah terbukti secara ilmiah memiliki aktivitas sebagai antimikroba. Sirih merupakan salah satu jenis tumbuhan yang banyak dimanfaatkan untuk pengobatan. Sirih termasuk dalah family Peperaceae dengan tumbuh merambat dan menjalar dengan tinggi yang dapat mencapai 5-15 meter tergantung pada pertumbuhan dan tempat untuk merambat. Hampir seluruh bagian tanaman sirih dapat digunakan, tetapi yang paling sering adalah pada bagian daun. Daun sirih dapat dimanfaatkan sebagai antimikroba dalam pembuatan handsanitizer. Dalam daun sirih mengandung senyawa kimia berupa saponin, flavonoid, dan polifenol. Senyawa saponin yang terkandung dalam daun sirih bekerja sebagai antimikroba, dengan mekanisme kerja yang akan merusak membran sitoplasma dan membunuh sel. Senyawa flavonoid dalam daun sirih dapat mendenaturasi protein sel bakteri dan merusak membran sel tanpa dapat diperbaiki lagi. Senyawa fenol memiliki mekanisme agen antimikroba yang berperan sebagai toksin dalam protoplasma, merusak, menembus dinding, serta mengendapkan protein sel bakteri (Carolia \& Wulan, 2016).

\section{Sirih merah}

Sirih merah (Piper ornatum) mengandung senyawa aktif seperti flavonoid, alkaloid, tanin, senyawa polifenol dan minyak atsiri (Lestari, 2014). Pada sirih merah, flavonoid memiliki efek antimikroba dengan membentuk senyawa kompleks yang menahan protein ekstraseluler yang merusak integritas membran sel (Juliantina, 2009). Alkaloid juga memiliki sifat antimikroba. Mekanisme yang mungkin dilakukan adalah dengan menghancurkan komponen peptidoglikan di dalam sel bakteri, sehingga lapisan dinding sel tidak dapat terbentuk secara sempurna dan mengakibatkan kematian sel. Tanin memiliki aktivitas antimikroba, tanin diduga dapat mengecilkan dinding sel atau membran sel, sehingga mengganggu permeabilitasnya. Sel tidak dapat melakukan aktivitas hidup, sehingga menghambat pertumbuhannya bahkan kematian (Ajizah, 2004).

\section{Bunga lawang}

Bunga lawang (Illicium verum) mengandung senyawa antimikroba yakni flavanoid dan tanin. Senyawa flavonoid bersifat disinfektan yang bekerja dengan cara mendenaturasi (menggumpalkan) protein pada mikroba. Akibat dari denaturasi sehingga menyebabkan aktivitas metabolisme sel bakteri terganggu. Tanin juga mempunyai daya antimikroba yang akan bereaksi dengan membran sel mikroba. Tanin bekerja dengan cara merusak polipeptida pada dinding sel mikroba, sehingga pembentukan 
dinding sel menjadi kurang sempura yang berakibat keluarnya isi sel bakteri atau lisis. Lisis disebabkan adanya tekanan osmotic yang berbeda dan dapat menyebabkan kematian pada bakteri (Puspita et al,. 2020)

\section{KESIMPULAN}

Dari hasil penelitian ini dapat disimpulkan jika bahan alam seperti sirih, sirih merah, serai, dan kayu lawang memiliki kemampuan antimikroba yang dibuktikan dengan uji antimikroba dengan kekuatan sedang. Dengan demikian bahan alam tersebut dapat dijadikan sebagai carian penyanitasi tangan, meskipun kekuatannya masih dibawah alkohol $70 \%$ dan cairan penyanitasi tangan komersial yang beredar di pasaran. Butuh penelitian lebih lanjut untuk mendapatkan formulasi antimikroba agar masuk dalam kategori kuat atau sangat kuat.

\section{DAFTAR PUSTAKA}

Acharya S.B., Ghosh S., YadavD., Sharma K., Ghosh S., Joshi S. (2018). Formulation, Evaluation and Antibacterial Efficiency of water-based herbal Hand Sanitizer Gel. Publons, $29 \quad$ Jul 2019. https://doi.org/10.1101/373928.

Ajizah A. (2004). Sensitivitas Salmonella typhimurium Terhadap Ekstrak Daun Psidium guajava L. Jurnal Bioscientiae Volume 1, Nomor 1.

Asngad A., Bagas R,A. Nopitasari.( 2018). Kualitas Gel Pembersih Tangan (Handsanitizer) dari Ekstrak Batang Pisang dengan Penambahan Alkohol, Triklosan dan Gliserin yang Berbeda Dosisnya. Jurnal Bioeksperimen. Vol. 4 (2) Pp. 61-70. Doi: 10.23917/bioeksperimen.v4i1.2795

Bassolé I.H.N., Lamien-Meda A., Bayala B., Obame L.C., Ilboudo A.J., Franz C., Novak J., Nebié R.C. \& Dicko R. (2011). Chemical composition and antimicrobial activity of Cymbopogon Citratus and Cymbopogon Giganteus Essential oils alone and in combination. Journal of Phytomedicine. (18): 1070-1074.
Candrasari A, Romas M.A., Hasbi M, Astuti O.R. (2012). Uji Daya Antimikroba Ekstrak Etanol Daun Sirih Merah (Piper Crocatum Ruiz \& Pav.) Terhadap Pertumbuhan Staphylococcus aureus ATCC 6538, Eschericia coli ATCC 11229 Dan Candida albicans ATCC 10231 SECARA IN VITRO. Biomedika. Vol.4(1): 9 - 16.

Carolia N, Wulan N. (2016). Potensi Ekstrak Daun Sirih Hijau (Piper betle L.) sebagai Alternatif Terapi Acne vulgaris. Journal Majority. Vol 5(1).

Davis W. W. dan T. R. Stout. (1971). Disc plate methods of microbiological antibiotic assay. Microbiology 22: 659-665.

Fauziah, H., Liina, A., \& Nurmiyati, N. (2018). Studi Etnobotani Tumbuhan Upacara Ritual Adat Kelahiran di Desa Banmati, Kecamatan Tawangsari, Kabupaten Sukoharjo. Biosfer : Jurnal Biologi Dan Pendidikan Biologi, 2(2), 24-28. doi:10.23969/biosfer.v2i2.657

Ferdes M. (2018). Antimicrobial compounds from plants. Fighting Antimicrobial Resistance, Edited by Ana Budimir, http://iapcobp.com/books/release_detail/15Chapter: Antimicrobial Compounds from plants (pages 273-271)Publisher: IAPC-OBP, Zagreb, Croatia.

Herbie, T. (2015). Kitab Tanaman Berkhasiat Obat. Octopus Publishing House. Yogyakarta

Hendrik G,W., Panggabena W, Sentosa A. (2016). Pemanfaatan Tumbuhan Serai Wangi (Cymbopogon Nardus (L.) Rendle) Sebagai Antioksidan Alami. Jurnal Kimia Mulawarman. Vol 2(1).

Jafari B., Amirreza E., Babak M.A., Zarifeh H. (2012). Antibacteria Activities of Lemon Grass Methanol Extract and Essence Pathogenic Bacteria. Journal of AmericanEurasian J. Agric and EnvironSci. 12(8): 1042-1046.

Juliantina, Citra, Nirwana, Nurmasitoh, dan Bowo. (2009). Manfaat Sirih Merah (Piper Crocatum) Sebagai Agen Anti Bakterial Terhadap Bakteri Gram Positif dan Gram Negatif. "Tidak diterbitkan. Laporam Penelitian. Yogyakarta: Fakultas 
Kedokteran Universitas Islam Indonesia Yogyakarta.

Kusnadi, K. (2017). Uji Toksisitas Ekstrak Tumbuhan Ageratum Conyzoides L.Terhadap Pertumbuhan Dan Fisiologi Darah Mencit. Biosfer : Jurnal Biologi Dan Pendidikan Biologi, 1(1), 1-9. doi:10.23969/biosfer.v1i1.203

Lestari D. Y. (2014). Aktivitas antioksidan ekstrak daun sirih merah (Piper crocatum) hasil optimasi pelarut etanol-air. Ilmu Kefarmasian Indonesia. Vol 12(1): 75-79.

Poeloengan, M. (2009). Pengaruh Minyak Atsiri Serai (Andropogon Citratus Dc.) Terhadap Bakteri Yang Diisolasidarisapi Mastitis Ubklinis. Berita Biologi 9(6): 715- 720.

Puspita D., Ardiawati E., Desi. (2020). Formulation and Antibacterial Test of Star Anise Extract (Illicium verum Hook.f) as a Handsanitizer. Jurnal Biologi Lingkungan, Industri dan Kesehatan. Vol. 7(1):90-96.

Rafles, T.S. (2014). The History of Java. Narasi. Yogyakarta.

Reveny J. (2011). Daya antimikroba ekstrak dan fraksi daun sirih merah (Piper betle Linn.). Sumatra Utara: Jurnal Ilmu Dasar. 12(1): 6-12.

Suliantari, Betty S.l, Jenie, Suhartono M.T. (2012). Aktifitas Antimikroba Fraksifraksi Ekstrak Sirih Hijau (Piper betle L) terhadap Patogen Pangan. Jurnal Teknologi dan Industri Pangan. Vol 23(2):217-220. 